\title{
The Competitiveness of Selected New Members of the EU in the Environmental Products and Services Market
}

\author{
Zofia Wysokinska \\ Department of World Economy and European \\ Integration at the University of Lodz \\ Poland
}

\section{Introduction}

In 2005, the Commission laid the foundations for an EU strategy to combat climate change. This document now sets out more concrete steps to limit the effects of climate change and to reduce the risk of massive and irreversible disruptions to the planet. These short-term and mediumterm measures target both developed countries (the EU and other industrialized countries) and developing countries (Communication from the Commission, 2007, COM 2007; final). One year before an environmental technologies action plan for the European Union was prepared by the European Commission in order to stimulate technologies for sustainable development (Communication from the Commission to the Council and the European Parliament, 2004, COM 2004; 38; final).

This action plan in favor of environmental technologies concerns technologies to manage pollution, less polluting and less resource-intensive products and services and ways to manage resources more efficiently. These environmentally friendly technologies pervade all economic activities and sectors. They cut costs and improve competitiveness by reducing energy and resource consumption and so creating fewer emissions and less waste (as above).

The Commission considers that the implementation of the priorities in the Action Plan is well underway, particularly in terms of establishing technology platforms and key orientation documents which should catalyze the development of environmental technologies, funding from the European Investment Bank (EIB) and the preparation for an international support fund. However, the Commission highlights the need to step up work in this area, in particular by mobilizing European risk funding, fixing environmental performance targets for products, processes and services, establishing an EU wide system for testing and verifying environmental technologies as part of work to revise the Guidelines for environmental State aids, defining market development and industrial performance indicators, setting up national implementing roadmaps and drawing up action plans for public procurement (Communication from the Commission-2005-COM 2005; 16).

While the United States and Japan take the lead in biotechnology and nanotechnology, the EU leads the way in environment-related technology (solid waste, renewable energy and 
motor vehicle abatement), with Germany playing a very active role. Japan is second to the EU in all three environmental technology fields (Highlights; OECD,2007).

It can be also stressed that among the 6 Lead Market Areas in Europe (according to the Lead Market Initiative) especially 4 environmentally friendly goods and services markets have been identified as highly innovative, respond to customer's needs, having a strong technological and industrial base in Europe and depend more than other markets on the creation of favorable framework conditions through public policy measures. Sustainable construction, recycling, bio-based products and renewable energies belong to these lead sectors, characterized by high economic and societal value (A lead market initiative for Europe; Communication from the Commission to the Council, 2007, COM 2007, 860, final).

CEE countries in their process of accession to the EU and adaptation to European environmental standards undertook significant steps in the 1990s to improve their natural environments, increasing their imports of goods designed to aid in environmental protection and technologies to implement "clean production" of export goods. These steps should improve the competitiveness of Polish, Czech, and Hungarian goods and products in the future on both the European and global markets. Research results confirm the proecological emphasis of transition economies' restructuring efforts, particularly when read together with the significant increase in their foreign trade in pro-ecological goods and services.

In the case of firms with foreign ownership the effect of compliance with environmental norms and standards on their share of the domestic market was very slight, while the effect of compliance with environmental norms and standards on their share of the export market is somewhat greater, but still modest. An analysis of the results shows that most foreign investors do take environmental protection issues into account in making their decisions, but they do not consider them to constitute a major investment factor. A majority of the respondents favor centralizing strategies. This strategy seems advantageous for recipient countries. Firms with foreign capital frequently introduce environmental protection norms and take part in environmental protection programs. ${ }^{1}$ Wysokińska Z,\& Witkowska J, 2005, p.279).

At present supporting sustainable growth -for a resource efficient, greener and more competitive economy is one of 3 objectives of the Strategy Europe 2020-main EU's growth strategy for the coming decade (Europe 2020, 2010). Sustainable growth means first of all protecting the environment, reducing emission and preventing biodiversity loss, capitalising on Europe's leadership in developing new green technologies and production methods in order to build a more competitive green and low carbon economy that makes efficient, sustainable use of resources (as above) .

\section{Characteristics of the market of environmental goods and services}

The environmental goods and services market is among those world markets that has demonstrated one of the highest growth rates in demand over the past ten to fifteen years. Its volume was assessed at approximately USD 518 billion in the year 2000 and projections for the year 2010 assume its growth to approximately 600 billion (in Trade and Environment Review 2003, United Nations,2004, p.36.). The low and irregular share of foreign trade in environmental services and world export in environmental services over various years is at 
a level of barely $0.3 \%-0.4 \%$ of what is produced. For comparison, world exports in environmental products is approximately $20 \%$ of their production. This shows a high disproportion in the trading of environmental products between its products and services sections.

The environmental industry (i.e. industry "working" for environmental protection) was characterized by an average growth rate of more than $10 \%$ over the past ten to fifteen years. However, the dynamics of its growth in the highly developed countries had a significantly lower rate, which barely amounted to approximately $1.6 \%-2 \%$. At the same time, the growth rate in developing countries was at a level of approximately $7 \%-8 \%$. Analysts expect the expansion of industry working for environmental protection as well as of the environmental services sector to a volume of more than USD 600 billion by the year 2010 . Projections show that such growth will be particularly characteristic of those countries and will amount to approximately $8 \%-12 \%$. Compared with other markets, it may be stated that the environmental products and services market is not as large as the steel or agricultural markets. However, its size is comparable with the pharmaceutical or information technology markets. The environmental products market encompasses three main segments - equipment (technical equipment), environmental services, and natural resources. Technical equipment obviously encompasses the most advanced technologies, while environmental services include simpler, albeit more common ones. The predicted growth of more than $15 \%$ in the sales of environmental services over the past decade is an additional approximately USD 42 billion increase in demand on the world market providing employment for approximately 1-2 million workers. It is the highly developed countries that are the largest producers of environmental services (United States - approximately 38\% of the world market, Japan - approximately 18\%, and Germany, Great Britain, France, and Italy). A mere approximately $2 \%$ make up the share of Eastern Europe (inclusive of the European part of the CIS), where the share of Poland is between $0.3 \%$ and $0.4 \%$ (Wysokińska , 2009, p. 941-948.).

The environmental markets in highly developed countries are extremely competitive. They have an exceedingly specialized consumer rights protection base. However, they are experiencing low or even negative growth in many sectors and are very "sensitive" to economic cycles. Environmental regulations are among the most important of market factors. The capacity to produce environmental products and services is growing dynamically in many developing countries primarily thanks to collaboration with established companies as well as due to increased demand on the internal market. Nevertheless, little data corroborate the fact that this is also reflected in export.

Present barriers in trade, understood as what are known as "bound tariffs," which are tied to many capital-intensive goods, serve as the base for the rendering of services in the area of waste management. They are low in highly developed countries (below 3\% for products found on the list of OECD countries). Many developing countries have their customs rates set a relatively high levels $-10 \%$ to $20 \%$. In certain cases the tariffs are exceptionally high. (Wysokinska Z., 2005.). In practice, the import of environmental products and services may benefit from many incentives. Technical regulations provide support in adapting environmental products and services to environmental requirements. The dearth of uniform environmental requirements on various national markets is a significant extra-tariff barrier. It is especially standards and certification that have an impact on trade in environmental 
products and services. On the other hand, trade in niche products searching for new markets may be hindered as a result of a lack of appropriate standards for such products. Thus, imported environmental technologies should be tested and certified by local authorities on individual markets. (Vikhlyaev A., 2004).

\section{Liberalization process within the WTO-the role of Multilateral Environmental Agreements}

Supra-national regulations relating to trade that include requirements taking into account aspects of environmental protection are encompassed by the Multilateral Environmental Agreements (MEA). This particularly pertains to non-discrimination in trade and transparency in exchanges. The gradual removal of tariff and extra-tariff barriers restricting trade in light of WTO regulations occurs simultaneously with the support and promotion of environmental protection within the strategy of sustainable development. WTO regulations relating to transparency in exchange create conditions for complementarities of trade policy and environmental protection policy. They provide a basis for analysis of product labeling and packing processes in line with environmental requirements as well as assessments by WTO experts as to whether they play a part in establishing new restrictions in international trade. Similar requirements also relate to products tied with merchandise safety and health protection as well as with respect to those WTO regulations that guard against the development of barriers restricting international trade. The integration of trade and the environment with respect to developing countries is one of the priority areas within the framework of sustainable development strategies. Intensive ongoing debates as well as pilot projects on regional and national levels are leading to evolution in actions as well as to initial visible results in this area. It is becoming clear that the integration of trade and the environment necessitates a concrete linking mechanism coupling various aspects on a national and international activity level.

In connection with the Report from the 5th Session of the WTO Ministerial Conference in Cancun, which continued work launched within the framework of the regular sessions of the Committee on Trade and Development (CTE) in the period between the 4th WTO Ministerial Conference in Doha and the 5th in Cancun, it is stated that improved market access for developing countries is a key objective in implementation of sustainable development. Attention is called to the fact that in light of the Principles of Rio de Janeiro (Rio Principle 114 th), environmental standards and priorities should in particular mirror the environmental and developmental context to which they refer, where standards as applied by certain countries may result in improper and unjustified economic and social costs for others, especially developing countries. Small and medium businesses are particularly "sensitive" to their application.

Many WTO member states call attention to the fact that environmental and health protection legitimize the integration of environmental and trade policy and that countries have the right to introduce their own appropriate level of environmental protection in line with such objectives. However, it is noted that environmental standards should also influence exports. Thus, the aim of any action should not be the lowering of these standards, but rather facilitating adapting to them by exporters. (In this case, technical assistance, support of competitive capacity, and the transfer of technology serve a key role in helping 
exporters from developing countries in adapting to standards and implementing appropriate production methods.) Many WTO members put particular weight on identifying trade potential for sustainable growth during discussions on future directions of development. The Committee on Trade and Development (CTE) should point to incentives and instruments supporting developing countries in the process of identifying products and developing export markets for environmentally friendly products in areas where many of these countries achieve a comparative advantage. (as above, p. 944).

\section{Environmental market in Poland in comparison to other European countries}

Products fostering environmental protection ${ }^{1}$ have gradually increased their share in total trade turnover in Poland from approximately $3 \%$ to $4.5 \%$ on the side of exports and from $5 \%$ to approximately $7 \%$ on the side of imports. These changes were particularly noticeable in the European direction (as above, p. 944).

In its turn, import growth in Poland was even greater. Over the examined period it increased from USD 2.630 million in the year 2000 to USD 6.058 million in the year 2005. In the direction of imports from the European Union, growth went from USD 2.001 billion to USD 4.766 billion. The increase in share of products fostering environmental protection in Polish imports was even greater and amounted to an increase from $5.4 \%$ in the year 2000 to $6.0 \%$ in 2005 in overall imports, and growth from $6.7 \%$ to $8.2 \%$ in imports from the European Union. This indicates growing interest in Poland in international trade of products fostering environmental protection, which is a very positive phenomenon in this time of implementation of the Sustainable Development Strategy and the gradual lowering of barriers so as to improve access to developing markets of environmental products and services in both highly developed and developing countries.

A sales volume at a level of USD 169-179 billion characterized the world environmental services market over the years 1999-2003. World product over this period amounted to approximately USD 169-178 billion, while trade in environmental services was at a level of approximately $0.3-0.4$ of the share in world service production. This put its value at a level of from USD 495 million to 654 million on the side of exports and from USD 519 million to 7159 million on the side of imports.

The world environmental services market was dominated by the economically highly developed countries, including mainly the countries of Western Europe that have a total share of approximately $40 \%$ over the examined period, with a growing tendency up to the year 2000. From among this group of countries, the share of the European Union was at a level of $38.8 \%$ in 2002, while the respective share of EFTA was $2 \%$. From among the countries of the European Union, of greatest importance in terms of share in the world environmental services market, main positions were occupied by countries such as Germany (approximately 9\%), Great Britain (approximately 8\%), France (approximately 6\%)

1Products fostering environmental protection were classified into three basic groups: 1) Products and services related to waste management, 2) Cleaning technologies and products, and 3) Products relating to managing processes preventing the creation of pollution. More on this topic may be found in Wysokińska Z., "The International Environmental Goods and Services Market ...," (Wysokinska Z., 2005., p. 943). 
Italy and the Netherlands (approximately 4\%, each), and Denmark (approximately 3\%). Important positions in the world environmental services market from among the nonEuropean countries of the OECD were occupied by such countries as the United States (approximately 28\%) and Japan (approximately 13\% with a slightly downwards tendency over the whole of the examined period). Central and Eastern Europe as well as the European countries of the CIS held a total approximately $2 \%$ share in the volume of the examined market, where the share of the countries of Central and Eastern Europe was at a level of approximately $1.4 \%$ in the year 2002 and had a strongly growing tendency over the whole of the examined period (1999-2002). The lowest position from among the countries of Central and Eastern Europe was occupied by Poland (approximately $0.43 \%$ in the year 2002), followed by the Czech Republic (approximately 0.37\%) and Hungary (approximately $0.30 \%)$ ), where all three had a growth tendency in their shares over the analyzed years.

As can be seen from the conducted analysis, the share of trade in environmental services in the production of environmental services is relatively small and does not exceed $0.4 \%$ of world trade. Total world exports in environmental services amounted to USD 654 million in the year 2002, with a systematic growth tendency over recent years (from a level of USD 495 million in the year 2000). Western Europe held an $84 \%$ share in world exports and an $86 \%$ share in world imports in these services. The share of the United States barely exceeded 3\% while for Japan the figure was approximately $1.3 \%$ on the side of exports (with a downward tendency in the case of both countries) and approximately $2.5 \%$ and approximately $2 \%$, respectively, on the side of imports (with a downward tendency for Japan and growth in share for the United States). Among the countries of the European Union, which holds a $70 \%$ share in world exports of environmental services, France was dominant (a 25\% share in world exports), followed by the Netherlands (a 16\% share) and Belgium (a 12\% share). The EFTA countries (with a dominant position held by Switzerland) held a $14 \%$ share in world exports of environmental services. The specified countries of Western Europe were also significant importers of environmental services, which bears witness to the high level of advancement of intra-industry trade in environmental services in this area. Central and Eastern Europe as well as the European countries of the CIS held an approximately $3 \%$ share in world exports and an approximately $2 \%$ and $1 \%$ share, respectively, in world imports of environmental services, with a simultaneous significant growth tendency on the side of exports. A strongly growing share in the export of these services was also noted in Estonia, which achieved $0.72 \%$. Among the countries of Central and Eastern Europe, the greatest share in exports was demonstrated by the Czech Republic $(0.98 \%)$, followed by Poland $(0.6 \%)$ and Hungary $(0.5 \%)$.

Two major groups may be identified on the environmental services market in Poland - basic services for the environmental sectors and environmental cluster sector services. The former group includes sewage management and water protection, where this sector includes water distribution services by pipelines, excluding hot water (PKWiU Polish Classification of Products and Services, Section 41) and sewage management (PKWiU, Category 90.00.1), waste management, including the disposal of garbage and wastes (PKWiU, Category 90.00.2), contract-based metal waste and scrap processing (PKWiU, Section 37), wholesale and retail trade in wastes, scrap metal, and other materials for recycling (51.57.10, ex51.18.12, ex52.48.12), snow removal, etc. services (PKWiU, Category 90.00.3), and storage services (PKWiU, Sub-category 63.12.12). The latter group includes environmental research 
and development services, advisory services, contracts and environmental engineering, analysis services, data collection, estimates, construction, transportation, and other services (including spatial planning services).

Poland's share in the world services market oscillates in the area of $0.4 \%$ to $0.5 \%$. The share of environmental services exports measured on the basis of the balance of payments is at a similar level. Imports are at a level in the area of $0.15 \%$ to $0.20 \%$, however, the positive trade balance calculated only in the area of basic sectors provides USD 1 to 2 billion annually. If environmental cluster sectors are added to this as well as those for which there is no detailed data in this area, then the balance of turnover in environmental services may reach a level of 30\% (approximately) more, although for research and development, design, and engineering services the balance will be negative.

Analysis of the Polish market for environmental services was conducted in line with European Union propositions for modifications of the GATS/WTO classification system because it contains the entire classification and is its expansion modernized by almost a decade. It provides for the subdivision of services into basic sectors like the W/120 GATS/WTO classification system, but it allows for a more accurate disaggregation of environmental cluster sectors, accounting for a single aspect of the activities of those sectors in the area of environmental designations.

The export of environmental services by companies in Poland has been rising, where growth in the year 2001 as compared to 2000 amounted to 36.3 percentage points, while in 2003 as compared with 2002 is almost doubled and amounted to 66.9 percentage points. The volume of environmental services exports was very small over the whole of the analyzed period, however. Growth in exports in the environmental sectors is about one-third greater than growth in their sales on the domestic market in terms of average percentages. The rate of growth of exports is, in general, satisfactory, with an average of over one dozen percentage points per annum. However, this applies to too small an amount and at this time does not have any significant impact on economic results.

Analysis of the collective economic results of business entities rendering environmental services in Poland demonstrates that among all the entities providing environmental services, profit-making companies were dominant during the examined period (from approximately $73 \%$ in the year 2000 to $72 \%$ in the year 2003). The share of companies achieving good financial results was high among large- and medium-sized companies as well as small ones. However, it was among the ones considered large in terms of numbers of employees that is was significantly higher. Both in public sector entities and private ones those that achieved a positive financial result were dominated by companies providing environmental services, but the share of private companies in this group was greater. A less positive phenomenon was that in both analyzed groups (though to a lesser extent in the private sector), the share of entities making a profit over the analyzed 2000-2003 period decreased.

As can be seen from the analysis presented in the report, both the environmental market and in particular the environmental services market are a part of markets having the greatest development potential in today's world economy. This is borne out by the high rate of its development, especially in the countries of systemic transformation and developing countries. Although presently still holding a relatively small share in this dynamically developing market, the rate of change in this area found in those countries over recent years allows their placement among its potentially growing participants. 
Environmental market analysts expect the expansion of industries working for environmental protection as well as the environmental services sector to a size of more than USD 600 billion by the year 2010. This is when the share in growth potential of the systemic transformation countries of Central and Eastern Europe as well as the countries of the CIS, mainly Russia, may gradually become more important in the long term. It is expected that this growth will be particularly characteristic of environmental cluster developing countries as well as systemic transformation ones and that the growth rate of these countries will amount to approximately $8 \%-12 \%$.

Although the countries of Western Europe and other highly developed countries hold dominant shares in the world environmental services market, they have been facing a steady decline in the development of exports of these services over recent years. Due to growing operating costs in the environmental services sector in those countries, which is mainly the result of their high salary levels, it may be expected that in the upcoming years there will be greater expansion and investments by Western European companies (mainly from the countries of the European Union such as France, the Netherlands, and Belgium as well as Switzerland) as well as from other highly industrialized economies in both developing countries and in countries that have recently undergone systemic transformation. These particularly include countries from the Central and Eastern Europe region, including mainly the three greatest producers of environmental services in this area, which includes Poland, the Czech Republic, and Estonia, as well as Russia.

The better and continuously improving access to the world environmental market is witnessed by the previously carried out liberalization of trade within the framework of OECD countries in line with WTO requirements as well as in the significantly slower, but nevertheless present, rate of liberalization taking place in trade in developing countries.

The market volume of developing countries in the area of environmental services may be estimated as being an approximately $8.5 \%$ share of the world market, with a steady growth tendency over recent years. Their share in world exports and imports of these services oscillated around the $6 \%-7 \%$ mark in world trade while in world environmental services production in exceeds an $8 \%$ share. This shows the growing involvement of both domestic environmental service providers in these countries and the even greater degree of growth in foreign investments (from the highly developed countries) in this sector, potentially one of the most dynamically developing sectors of the world economy. ${ }^{2}$

\section{Conclusions}

As can be seen from the presented analysis, both the environmental products market and the environmental services market are among markets with the greatest development potential in today's world economy.

This is borne out by the high rate of their development, especially in the systemic transformation and developing countries that, albeit still holding a relatively small share in

2These conclusions are derived from an expert report entitled "Ocena szans Polski na międzynarodowym rynku wyrobów i usług środowiskowych" [An assessment of Poland's chances on the international environmental product and services market] developed by the author for the Ministry of the Economy in 2007. 
this dynamically developing market, demonstrate a rate of change in this area allowing these countries to be placed among its potentially growing participants.

CEE countries in their process of accession to the EU and adaptation to European environmental standards undertook significant steps in the 1990s to improve their natural environments, increasing their imports of goods designed to aid in environmental protection and technologies to implement "clean production" of export goods. These steps should improve the competitiveness of Polish, Czech, and Hungarian goods and products in the future on both the European and global markets.

As a member state of the European Union, Poland should make an active entry with its production and sales in these dynamically developing segments of the market and take advantage of available benefits, simultaneously playing a role in improving the state of the natural environment in countries of the world most in need of such products and technologies.

\section{References}

A lead market initiative for Europe; COMMUNICATION FROM THE COMMISSION TO THE COUNCIL, THE EUROPEAN PARLIAMENT, THE EUROPEAN ECONOMIC AND SOCIAL COMMITTEE AND THE COMMITTEE OF THE REGIONS; COM (2007) 860 final, Brussels, 21.12.2007.

Communication from the Commission, of 10 January 2007, entitled: "Limiting Global Climate Change to 2 degrees Celsius - The way ahead for 2020 and beyond" [COM(2007) 2 final - Not published in the Official Journal];

http://europa.eu/legislation_summaries/environment/tackling_climate_change/1 28188_en.htm.

Communication from the Commission to the Council and the European Parliament of 28 January 2004 entitled: "Stimulating technologies for sustainable development: an environmental technologies action plan for the European Union" [COM(2004) 38 final - Not published in the Official Journal].

Communication from the Commission of 27 January 2005: Report on the implementation of the Environmental Technologies Action Plan in 2004 [COM(2005) 16 - Official Journal C 123 of 21.05.2005].

"Environment Business International, Inc.," in Environmental Benefits of Removing Trade Restrictions and Distortions, Note by the Secretariat, Addendum, Committee on Trade and Environment. WT/CTE/W/67/ADD.1, March 13, 1998; “Implications of WTO Agreements for International Trade in Environmental Industries," ITC, 1999, in Trade and Environment Review 2003, United Nations, Geneva, New York, 2004.

http:/ /ec.europa.eu/economy_finance/structural_reforms/europe_2020/index_en.htm Highlights OECD Science, Technology and Industry Scoreboard 2007; OECD 2007.

Vikhlyaev A., "Environmental Goods and Services: Defining Negotiations or Negotiating Definitions?" in Trade and Environment Review 2003, United Nations, New York, Geneva, 2004, article 2.

Wysokińska Z., "Foreign Trade in Environmental Products; The WTO Regulation and Environmental Programs," Global Economy Journal, Volume 5, Issue 3, Article 5, US 2005, http://www.bepress.com/gej/vol5/iss3/5. 
Wysokińska Z., "The International Environmental Goods and Services Market: An Opportunity for Poland," Polish Journal of Environmental Studies, Vol. 18. No 5 (2009), pp. 941-948.

Wysokińska Z,. Witkowska J., International Business and Environmental Issues - Some Empirical Evidence from Transition Economies, Polish Journal of Environmental Studies, Vol. 14 No. 3 (2005), pp.269-279. 


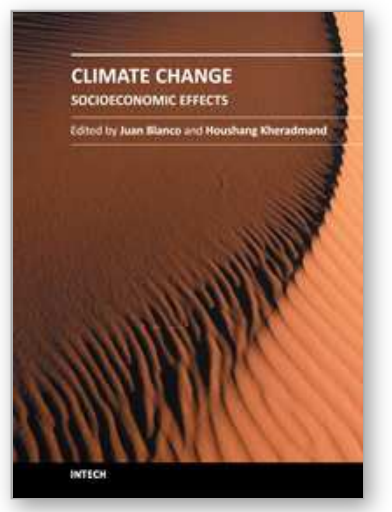

\author{
Climate Change - Socioeconomic Effects \\ Edited by Dr Houshan Kheradmand
}

ISBN 978-953-307-411-5

Hard cover, 454 pages

Publisher InTech

Published online 09, September, 2011

Published in print edition September, 2011

This book shows some of the socio-economic impacts of climate change according to different estimates of the current or estimated global warming. A series of scientific and experimental research projects explore the impacts of climate change and browse the techniques to evaluate the related impacts. These 23 chapters provide a good overview of the different changes impacts that already have been detected in several regions of the world. They are part of an introduction to the researches being done around the globe in connection with this topic. However, climate change is not just an academic issue important only to scientists and environmentalists; it also has direct implications on various ecosystems and technologies.

\title{
How to reference
}

In order to correctly reference this scholarly work, feel free to copy and paste the following:

Zofia Wysokinska (2011). The Competitiveness of Selected New Members of the EU in the Environmental Products and Services Market, Climate Change - Socioeconomic Effects, Dr Houshan Kheradmand (Ed.), ISBN: 978-953-307-411-5, InTech, Available from: http://www.intechopen.com/books/climate-changesocioeconomic-effects/the-competitiveness-of-selected-new-members-of-the-eu-in-the-environmentalproducts-and-services-mar

\section{INTECH}

open science | open minds

\section{InTech Europe}

University Campus STeP Ri Slavka Krautzeka 83/A

51000 Rijeka, Croatia Phone: +385 (51) 770447

Fax: +385 (51) 686166

www.intechopen.com

\section{InTech China}

Unit 405, Office Block, Hotel Equatorial Shanghai

No.65, Yan An Road (West), Shanghai, 200040, China 中国上海市延安西路65号上海国际贵都大饭店办公楼 405 单元 Phone: +86-21-62489820

Fax: $+86-21-62489821$ 
(C) 2011 The Author(s). Licensee IntechOpen. This chapter is distributed under the terms of the Creative Commons Attribution-NonCommercialShareAlike-3.0 License, which permits use, distribution and reproduction for non-commercial purposes, provided the original is properly cited and derivative works building on this content are distributed under the same license. 